\title{
Bats roosting in public buildings: A preliminary assessment from Moramanga, eastern Madagascar
}

\author{
Noromampiandra Razafindrakoto', Alexandra \\ Harwell" and Richard K. B. Jenkins III, IV $^{\prime \prime}$
}

\begin{abstract}
Madagascar has many synanthropic bat species but relatively little is known about how people interact with them. A preliminary assessment on the presence of bats in buildings and their interactions with people was conducted in the eastern town of Moramanga. Fifty of the 156 buildings were reported to contain active bat colonies and 46 of these were in schools. The bats, two species of Molossidae, roosted principally in the roof spaces of buildings that were more than ten years old. Users of the buildings were relatively tolerant of the bats, although $41 \%$ reported negative attitudes because of the odor of roosting colonies and some concerns over the possibility of contracting respiratory ailments from bat faeces. Guano accumulated in classrooms and was observed on floors and desks. Basic renovations could improve the learning environment for children and could be conducted in a bat-friendly way. More research is needed to assess the health risks to people from interacting with bats in Madagascar, and this includes people who study, eat, and handle bats or work and live in buildings or caves where bats roost.
\end{abstract}

\section{RÉSUMÉ}

Certaines espèces de chauves-souris ont su s'adapter à I'environnement humain et ont ainsi colonisé certaines parties des constructions humaines. Pourtant, de nombreuses espèces de chauves-souris sont associées à certaines maladies émergeantes. Madagascar possède plusieurs espèces synanthropiques de chauves-souris dont quelques unes associées à des virus alors que l'interaction de ces animaux avec les gens est très peu connue. Pour mieux comprendre ce phénomène, nous avons mené une étude préliminaire sur la présence de chauves-souris et de leurs interactions avec les gens dans des constructions urbaines, plus particulièrement dans des bâtiments publics (ceux de l'éducation ou de la santé) à Moramanga, une ville située dans la partie orientale de l'île. Des enquêtes informelles ont été réalisées auprès des usagers de ces enceintes et des comptages nocturnes de chauves-souris ont été effectués pour certains de ces bâtiments au moment où ces animaux quittaient leur dortoir. Les chauves-souris ont

\author{
Correspondence: \\ Richard K. B. Jenkins \\ Madagasikara Voakajy \\ B.P. 5181, Antananarivo (101), Madagascar \\ E-mail: jenkins@moov.mg
}

été identifiées grâce à des photos ainsi qu'à partir de mesures et caractéristiques morphométriques des individus capturés à I'aide de filets fauchoirs. Nous avons étalé des films en plastique pour récolter les fèces de chauves-souris dans les combles ou dans des salles de classes, et nous avons également recueilli les guanos amassés après le nettoyage des salles de classe. Les fèces ont été pesées avec des Pesola. Sur les 156 constructions répertoriées, une cinquantaine était habitée par des chauvessouris. La présence de ces animaux a été confirmée dans la plupart des écoles visitées (46 sur 65) mais pas dans les bâtiments hospitaliers et les centres médicaux. Les chauves-souris représentées par deux espèces de Molossidae, vivaient dans des combles de bâtiments publics construits depuis plus de dix ans. Les personnes utilisant ces bâtiments étaient relativement tolérantes sur la présence des chauves-souris bien que $41 \%$ relevait des attitudes négatives portant soit sur l'odeur dégagée par les colonies, soit sur des affections respiratoires attribuées aux fèces de ces chauves-souris, de sorte que certains occupants de ces bâtiments publics ont essayé, mais en vain, de se débarrasser de ces animaux. Les matières fécales s'accumulaient dans les salles de classe et ont été observées sur le sol et les bureaux. Des réparations élémentaires pourraient améliorer l'environnement éducatif pour les enfants et pourraient être conduites de manière à ne pas menacer les chauves-souris. Des recherches supplémentaires sont nécessaires pour évaluer les risques sanitaires des interactions avec les chauves-souris à Madagascar, et plus particulièrement pour les gens qui étudient, consomment ou touchent les chauvessouris, et même ceux qui travaillent ou vivent dans des immeubles ou des grottes où les chauves-souris gîtent.

KEY-WORDS: Madagascar, Moramanga, building, bats, health. MOTS CLEFS : Madagascar, Moramanga, bâtiments, chauvessouris, santé.

\section{INTRODUCTION}

World wide, bats of many species live synanthropically in urban areas using human-made structures such as houses, 
schools, offices and bridges for roosting during the day (Kunz and Lumsden 2005). Bats are known in different parts of the world as vectors of certain pathogens, including the rabies virus (Messenger et al. 2005, Schneider et al. 2009) and the fungus Histoplasma capsulatum, which can develop on bat faeces under particular conditions (Lewis 1989, Gugnani and Muotoe-Okafor 1997, Taylor et al. 1999). Additionally, there is evidence that bats in some regions may serve as reservoirs of other viruses such as, or closely related to, Severe Acute Respiratory Syndrome coronavirus (SARS), Hendra, Nipah, Marburg, Ebola, and Tioman (Breed et al. 2006, Calisher et al. 2006, Wong et al. 2007, Yaiw et al. 2007). Thus, there is a potential risk of disease transmission when people are in close or regular contact with bats and this is an area of research that requires more attention.

In Madagascar, synanthropic species belong to the EmbalIonuridae, Molossidae and Vespertilionidae (Peterson et al. 1995, Goodman and Cardiff 2004, Goodman et al. 2005, Ratrimomanarivo and Goodman 2005, Andrianaivoarivelo et al. 2006, Rakotonandrasana and Goodman 2007, Goodman et al. 2008). Research has so far tended to focus on taxonomy and ecology and little is known about the interactions between people and bats, despite the apparent high occupancy rate of theses species in certain types of buildings (Ratrimomanarivo et al. 2007, 2009). Some Malagasy bats, however, are known to be associated with pathogens including haemoparasites, and viruses (Raharimanga et al. 2003, Rousset and Andrianarivelo 2003, lehlé et al. 2007). A short survey of buildings in Moramanga, eastern Madagascar, was therefore conducted to assess the occurrence of bats roosting in public buildings and to obtain some preliminary data on guano accumulation. Information on the perception of people towards bats was also collected.

\section{METHODS}

The study was conducted in Moramanga, an urban commune in the Alaotra Mangoro Region with about 30,000 inhabitants, in eastern Madagascar (E48 $13^{\prime} 45^{\prime \prime}$, S18 $56^{\prime} 50^{\prime \prime}$ ) during November 2008. Local offices of the Ministère de l'Enseignement National et de la Recherche Scientifique - Ministry of National Education and Scientific Research (MENRS), Ministère de l'Environnement et des Forêts - Ministry of Environment and Forests (MEF), and Ministère de la Santé et du Planning Familial - Ministry of Health and Family Planning (MSPF) were visited to obtain information on the location of public buildings. Because of the potential health risk from bat faeces the survey focused on schools and hospitals and 26 locations were visited in total. Directors at each location were questioned about the construction history of the buildings and about the presence of bats. Information on the construction materials and architecture of each building were also noted.

At dusk, around 1800h-1930h, two or three people were positioned at key locations around the building from where they counted bats with hand counters. Bats were counted as they emerged from roosts in nine buildings. Species were identified from photos of roosting bats or individuals caught in hand nets as they emerged from the roost. Morphometric measurements (weight, length of forearm), pelage color and additional morphological characteristics were then used to identify the species (Peterson et al. 1995). Trapping and emergence counts were not conducted systematically at all sites. Statistical assessments of occupancy were not undertaken because buildings were not selected randomly.
Three plastic sheets ( $1 \mathrm{~m} \times 4 \mathrm{~m}$ each) were placed in the attic of three buildings, directly under the roosting bats, and on the floor of one building where faeces accumulated to investigate the deposition rate of faeces. These plastic sheets were placed and removed by people familiar with the building and who periodically enter the attic to remove guano. In another four buildings, the routine of school children includes sweeping the floor clean of bat faeces each morning and the swept deposits were kept for later collection when the faecal pellets were removed by two of the authors ( $\mathrm{NR}$ and $\mathrm{AH}$ ). The guano collections were later weighed using a $10 \mathrm{~g}$ Pesola scale (accuracy $\pm 0.3 \%$ ) and the deposition rate per day was calculated for each square meter when plastic sheets were used. To assess people's perception of the bats, open informal interviews were conducted with 27 individuals who managed and worked in the buildings to ascertain if they considered the bats a nuisance or problem.

\section{RESULTS}

A total of 156 buildings were visited, of which 50 housed bat colonies. Bats inhabited 46 of the 65 school buildings surveyed. Fewer hospital buildings and medical centres were occupied by bats (Table 1). Roofing material was metal in all but one of the buildings surveyed. Walls of the buildings surveyed were mostly constructed of bricks or bamboo and mud, with $35 \%$ and $31 \%$ of such buildings occupied by bats, respectively (Table 1 ). Ceilings were either absent or constructed from wood, bamboo and mud or plastic. The occupancy rate of buildings with hardboard ceilings was the highest (Table 2). Buildings less than 10 years old did not contain roosting bats.

Evening counts yielded estimates of emerging bats that varied between two and $262(66.1 \pm 81.3 \mathrm{SD} ; \mathrm{n}=9)$. Two bat species were identified during the survey: Peter's wrinklelipped bat (Mormopterus jugularis) and Little free-tailed bat (Chaerephon pumilus), both of which are Least Concern on the

TABLE 1. Fifty public buildings were occupied by bats in the eastern town of Moramanga in Madagascar. Schools with brick walls and wooden ceilings were frequently used by bats.

\begin{tabular}{|c|c|c|c|c|}
\hline Building type & Total & $\begin{array}{l}\text { With } \\
\text { bats }\end{array}$ & $\begin{array}{l}\text { Without } \\
\text { bats }\end{array}$ & $\%$ Occupancy \\
\hline Primary school & 74 & 18 & 56 & 24.3 \\
\hline Secondary school & 15 & 8 & 7 & 53.3 \\
\hline High school & 22 & 20 & 2 & 90.9 \\
\hline Hospital & 27 & 2 & 25 & 7.4 \\
\hline Medical centre & 4 & 0 & 4 & 0.0 \\
\hline Other & 14 & 2 & 12 & 14.3 \\
\hline \multicolumn{5}{|l|}{ Construction materials } \\
\hline \multicolumn{5}{|l|}{ Walls } \\
\hline Brick (with cement layer) & 118 & 41 & 77 & 34.7 \\
\hline Concrete & 1 & 0 & 1 & 0.0 \\
\hline Bamboo and mud & 29 & 9 & 20 & 31.0 \\
\hline Wood & 8 & 0 & 8 & 0.0 \\
\hline \multicolumn{5}{|l|}{ Ceilings } \\
\hline None & 53 & 10 & 43 & 18.9 \\
\hline Hardboard & 46 & 26 & 20 & 56.5 \\
\hline Timber & 50 & 10 & 40 & 20.0 \\
\hline Bamboo and mud & 1 & 1 & 0 & 100.0 \\
\hline Plastic & 3 & 3 & 0 & 100.0 \\
\hline Unknown & 3 & 0 & 3 & 0.0 \\
\hline
\end{tabular}


TABLE 2. Bat faeces accumulated on ceilings and directly on the floor of classrooms in Moramaga (EPP: Primary School; CEG: High school; Lycée: Secondary school).

\begin{tabular}{|c|c|c|c|c|}
\hline Locations & Days (n) & Method & Sampling surface area (m2) & Total mass of faeces collected ( $\mathrm{g}$ ) \\
\hline \multicolumn{5}{|l|}{ Attic } \\
\hline Ministry of Environment and Forests & 2 & Ceiling/sheet & 12 & 0.5 \\
\hline CEG Moramanga Ambony & 2 & Ceiling/sheet & 12 & 4.5 \\
\hline Lycée Razafindrabe Victorian & 2 & Ceiling/sheet & 12 & 6 \\
\hline \multicolumn{5}{|l|}{ Room } \\
\hline EPP Moramanga Ambony & 3 & Floor/sweeping & $\mathrm{n} / \mathrm{a}$ & 6 \\
\hline EPP Tsaralàlana & 2 & Floor/sweeping & $\mathrm{n} / \mathrm{a}$ & 0.02 \\
\hline EPP Ankazobe & 3 & Floor/sweeping & $\mathrm{n} / \mathrm{a}$ & 6.3 \\
\hline Lycée Technique & 4 & Floor/sheet & 12 & 2.7 \\
\hline Lycée Razafindrabe Victorian & 1 & Floor/sweeping & $\mathrm{n} / \mathrm{a}$ & 0.5 \\
\hline
\end{tabular}

IUCN Red List of Threatened Species (Andriafidison et al. 2008, Mickleburgh et al. 2008). Guano collection in the attics accumulated at $1.83 \mathrm{~g} \pm 1.42 \mathrm{SD}$ per day. In the buildings where faecal accumulation in rooms was measured, up to $2.0 \mathrm{~g}$ per day was collected. If deposition rates were consistent throughout the year, this equates to a maximum of about $0.7 \mathrm{~kg}$ of bat faeces per classroom.

Twelve of 27 interviewees from 10 buildings indicated that the presence of bats was a concern. Health and hygiene was the most commonly cited concern ( $n=9)$, followed by building deterioration putatively caused by accumulated faecal and urinary matter $(n=3)$. Health complaints attributed to the bats by the interviewees were mainly 'flu-like infection' or 'sore throats', as well as indisposition caused by the smell. The director of one school reported that sacks of guano were collected from the attic space of one building when the roof and the ceiling were renovated in 2004 . The guano was used as fertilizer. In four buildings, the occupants tried unsuccessfully to exterminate or to exclude bats from buildings by using pesticides or by sealing entrance holes.

\section{DISCUSSION}

Two species of molossid bats roosted in the public buildings (mainly schools) in Moramanga. The sampling of bats in this study was incomplete and, as other synanthropic species are known from the area, it is likely that other bat species were also roosting in the buildings (Andrianaivoarivelo et al. 2006). Also, because the sampling was biased towards public buildings and no information on bat presence was collected from private homes, shops or factories, the results in this study pertain only to the sample of buildings visited and are not more widely representative of urban areas in Moramanga.

Molossid bats in Madagascar are generally cave or crevicedwellers but have made use of the roosting opportunities available in man-made structures (Ratrimomanarivo et al. 2007, 2009). Mormopterus jugularis is frequently found roosting in civic or municipal buildings, such as schools and offices, which were mainly constructed in the French colonial architectural style that features a suspended ceiling and aeration holes through which the bats gain access (Racey et al. 2010). In this study, occupancy rates were high in brick buildings older than ten years that had a hardboard ceiling.

Classical (Histoplasma capsulatum) and African histoplasmosis (Histoplasma capsulatum var. duboisii) are associated with bats and both have been recorded in Madagascar (Gugnani 2000, Rakotoarivelo et al. 2010). The extent to which a bat colony poses a health risk is dependent on disease incidence in the colony and on the frequency and closeness of contact with humans. Guano accumulates more frequently under weak or damaged ceilings and buildings that are poorly maintained present increased risk of exposure to, or contact with, bat faeces. In some schools the pupils were expected to clean the nightly faecal deposits as part of their daily routine. The accumulation of guano in classrooms might pose a health risk through the inhalation of, or contact with, fungal spores and this is a key area of public health research in the future. simple repairs to the existing ceilings might quickly reduce the faecal-fall in the classrooms. Excluding bats from the buildings when they are away from the roost is also possible, but more challenging because they use multiple exit holes. The regular removal of faecal deposits in attics that can be safely accessed by people wearing respirators could also reduce the health risk to the human occupants and provide fertilizer for local use. Bat guano is marketed commercially in Madagascar from natural deposits and smaller scale enterprises from colonies in buildings may meet local demand in the future.

There is no clear procedure or legislation for dealing with unwanted bat colonies in Madagascar. Bats are frequently eaten by people in Madagascar (Jenkins and Racey 2008, Goodman et al. 2008), and can be legally hunted outside of strict nature reserves because they are classed as game (gibier) species in Malagasy law (Durbin 2007). Although legal provisions exist for issueing culling permits on a case-by-case basis for species that are dangerous to people or damage livelihoods, there is no provision for circumstances where the animals could be of a non-lethal public health concern.

Molossid bats in colonies in Madagascar frequently number in the hundreds and are found in both rural and urban settings, but local people rarely persecute these bats. There are no published accounts of bats culls in Madagascar and even when molossids are killed it appears to be primarily for food (Goodman et al. 2008). In Moramanga, a low frequency of anti-bat sentiment was reported by people, which suggests that, whilst the bats are unlikely to be popular, they are not yet considered a serious menace or a suitable source of protein. Direct contact between bats and people in Madagascar is low except for certain groups, such as people who trap, prepare or eat bats. Exposure to molossid faeces, however, is common in 
public buildings in Moramanga and probably also other towns in Madagascar. Disease prevalence in molossids and the risk posed from exposure to bat guano in Madagascar is relatively unknown and should therefore be an area of research in the future.

\section{ACKNOWLEDGEMENTS}

We would like to thank the mayor of Moramanga, Mr Ezechiel Rasolonjatovo, and those residents who participated in our study. The work was carried out in collaboration with the Département de Biologie Animale, Université d'Antananarivo and permission was granted by the government of Madagascar. We are grateful to the SIT Study Abroad Programme for funding and Madagasikara Voakajy. We thank Paul Racey and four anonymous referees for comments that greatly improved previous versions of this manuscript.

\section{REFERENCES}

Andriafidison, D., Cardiff, S. G., Goodman, S. M., Hutson, A. M., Jenkins, R. K. B., Kofoky, A. F., Racey, P. A., Ranivo, J., Ratrimomanarivo, F. H. and Razafimanahaka, H. J. 2008. Mormopterus jugularis. In: IUCN 2010. IUCN Red List of Threatened Species. Version 2010.1. <www.iucnredlist.org> accessed13 April 2010.

Andrianaivoarivelo, A. R., Ranaivoson, N., Racey, P. A. and Jenkins, R. K. B. 2006. The diet of three synanthropic bats (Chiroptera: Molossidae) from eastern Madagascar. Acta Chiropterologica 8, 2: 439-444. (doi:10 3161/150811006779398492)

Breed, A. C., Field, H. E., Epstein, J. H. and Daszak, P. 2006. Emerging henipaviruses and flying foxes - conservation and management perspectives. Biological Conservation 131, 2: 211-220. (doi:10.1016/j. biocon.2006.04.007)

Calisher, C. H., Childs, J. E., Field, H. E., Holmes, K. V. and Schountz, T. 2006. Bats: Important reservoir hosts of emerging viruses. Clinical Microbiology Reviews 19, 3: 531-545. (doi: 10.1128/CMR.00017-06)

Durbin, J. 2007. New legislation for the protection of Malagasy species. Lemur News 11: 4-6.

Goodman, S. M. and Cardiff, S. G. 2004. A new species of Chaerephon (Molossidae) from Madagascar with notes on other members of the family. Acta Chiropterologica 6, 2: 227-248. (doi:10.3161/1508110042955559)

Goodman, S. M., Andriafidison, D., Andrianaivorarivelo, R., Cardiff, S. G., Ifticene, E., Jenkins, R. K. B., Kofoky, A., Mbohoahy, T., Rakotondravony, D., Ranivo, J., Ratrimomanarivo, F., Razafimanahaka, J. and Racey, P. A. 2005. The distribution and conservation of bats in the dry regions of Madagascar. Animal Conservation 8, 2: 153-165. (doi:10.1017/ S136794300500199X)

Goodman, S. M., Ratrimomanarivo, F. H., Ranivo, J. and Cardiff, S. G. 2008. The hunting of microchiropteran bats in different portions of Madagascar. African Bat Conservation News 16: 4-7

Gugnani, H. C. 2000. Histoplasmosis in Africa: A review. The Indian Journal of Chest Diseases \& Allied Sciences 42: 271-277.

Gugnani, H. C. and Muotoe-Okafor, F. 1997. African histoplasmosis: A review. Revista Iberoamericana de Micologia 14: 155-159.

Iehlé, C., Razafitrimo, G., Razainirina, J., Andriaholinirina, N., Goodman, S. M., Faure, C., Georges-Courbot, M.-C., Rousset, D. and Reynes. J.-M. 2007. Henipavirus and Tioman virus antibodies in Pteropodid bats, Madagascar. Emerging Infectious Diseases 13, 1: 159-161. (doi:10.3201/eid1301.060791)

Jenkins, R. K. B. and Racey, P. A. 2008. Bats as bushmeat in Madagascar. Madagascar Conservation \& Development 3: 22-30.

Kunz, T. H. and Lumsden, L. F., 2005. Ecology of cavity and foliage roosting bats. In: Bat Ecology. T. H. Kunz and M. B. Fenton (eds), pp. 3-89. The University of Chicago Press, Chicago.

Lewis, W. C. 1989. Histoplasmosis: A hazard to new tropical cavers. The National Speleological Society Bulletin 51, 1:52-65.

Messenger, S. L., Rupprecht, C. E. and Smith, J. S., 2005. Bats, emerging virus infections, and the rabies paradigm. In: Bat Ecology. T. H. Kunz and M. B. Fenton (eds.), pp. 622-679. The University of Chicago Press, Chicago.
Mickleburgh, S., Hutson, A. M., Racey, P. A., Ranivo, J., Bergmans, W., Cotterill, F. P. D. and Gerlach, J. 2008. Tadarida pumila. In: IUCN 2010. IUCN Red List of Threatened Species. Version 2010.1. <www.iucnredlist.org> accessed 13 April 2010.

Peterson, R. L., Eger, J. L. \& Mitchell, L. 1995. Chiroptères. Faune de Madagascar, 84. Muséum national d'Histoire naturelle, Paris.

Racey, P. A., Goodman, S. M. \& Jenkins, R. K. B. 2010. The ecology and conservation of Malagasy bats. In: Islands Bats: Evolution, Ecology, and Conservation, T. H. Fleming and P. A. Racey (eds), pp. 369-404. The University of Chicago Press, Chicago.

Raharimanga, V., Ariey, F., Cardiff, S. G., Goodman, S. M., Tall, A., Rousset, D. \& Robert, V. 2003. Hémoparasites des chauves-souris à Madagascar. Archives de I'Institut Pasteur de Madagascar 69, 1-2: 70-76.

Rakotoarivelo, R. A. Razafimahefa, S. H, Andrianiaina, H. D. \& Randria, M. J. D. 2010. Une histoplasmose africaine chez un patient malgache immunocompétent. Bulletin de la Société de Pathologie Exotique 103, 1: 19-21. (doi:10.1007/s13149-009-0030-7)

Rakotonandrasana, E. N. and Goodman, S. M. 2007. Bat inventories of the Madagascar offshore islands of Nosy Be, Nosy Komba and Ile SainteMarie. African Bat Conservation News 12: 6-10.

Ratrimomanarivo, F. H. and Goodman, S. M. 2005. The first records of the synanthropic occurrence of Scotophilus spp. on Madagascar. African Bat Conservation News 6: 3-5.

Ratrimomanarivo, F. H., Vivian, J., Goodman, S. M. and Lamb, J. 2007. Morphological and molecular assessment of the specific status of Mops midas (Chiroptera: Molossidae) from Madagascar and Africa. African Zoology 42, 2: 237-253. (doi:10.3377/15627020(2007)42[237:MAMAOT]2.0.CO;2)

Ratrimomanarivo, F. H., Goodman, S. M., Taylor, P. J., Melson, B. and Lamb, J. 2009. Morphological and genetic variation in Mormopterus jugularis (Chiroptera: Molossidae) in different bioclimatic regions of Madagascar with natural history notes. Mammalia 73, 2: 110-129. (doi:10.1515/ MAMM.2009.032)

Rousset, D. and Andrianarivelo, M. R. 2003. Viruses. In: The natural history of Madagascar, S. M. Goodman and J. P. Benstead (eds.), pp 165-170. The University of Chicago Press, Chicago.

Schneider, M. C., Romijn, P. C., Uieda, W., Tamayo, H., da Silva, D. F., Belotto, A. da Silva, J. B. and Leanes, L. F. 2009. Rabies transmitted by vampire bats to humans: An emerging zoonotic disease in Latin America? Revista Panamericana de Salud Pública 25, 3: 260-269. (doi:10.1590/ S1020-49892009000300010)

Taylor, M. L., Chávez-Tapia, C. B., Vargas-Yanez, R., Rodriguez-Arrellanes, G., Pena-Sandoval, G. R., Toriello, C., Perez, A. and Reyes-Montes, M. R. 1999. Environmental conditions favoring bat infection with Histoplasma capsulatum in Mexican shelters. The American Journal of Tropical Medicine and Hygiene 61, 6: 914-919.

Wong, S., Lau, S., Woo, P. and Yuen, K.-Y. 2007. Bats as a continuing source of emerging infections in humans. Reviews in Medical Virology 17, 2: 67-91. (doi:10.1002/rmv.520)

Yaiw, K. C., Crameri, G., Wang, L., Chong, H. T., Chua, K. B., Tan, C. T., Goh, K. J., Shamala, D. and Wong, K. T. 2007. Serological evidence of possible human infection with Tioman virus, a newly described paramyxovirus of bat origin. The Journal of Infectious Diseases 196, 6: 884-886. (doi:10.1086/520817) 